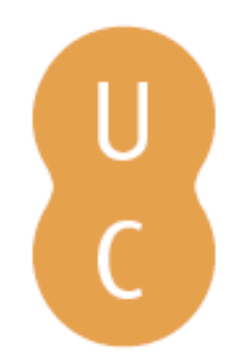

\title{
nommalina
}

\section{Better or more involved in politics? The involvement of portuguese voters in parliamentary elections}

\author{
Autor(es): $\quad$ Espírito Santo, Paula do \\ Publicado por: Imprensa da Universidade de Coimbra \\ URL \\ persistente: URI:http://hdl.handle.net/10316.2/35148 \\ DOI: $\quad$ DOI:http://dx.doi.org/10.14195/978-989-26-0917-1_4 \\ Accessed : $\quad$ 26-Apr-2023 08:57:45
}

A navegação consulta e descarregamento dos títulos inseridos nas Bibliotecas Digitais UC Digitalis, UC Pombalina e UC Impactum, pressupõem a aceitação plena e sem reservas dos Termos e Condições de Uso destas Bibliotecas Digitais, disponíveis em https://digitalis.uc.pt/pt-pt/termos.

Conforme exposto nos referidos Termos e Condições de Uso, o descarregamento de títulos de acesso restrito requer uma licença válida de autorização devendo o utilizador aceder ao(s) documento(s) a partir de um endereço de IP da instituição detentora da supramencionada licença.

Ao utilizador é apenas permitido o descarregamento para uso pessoal, pelo que o emprego do(s) título(s) descarregado(s) para outro fim, designadamente comercial, carece de autorização do respetivo autor ou editor da obra.

Na medida em que todas as obras da UC Digitalis se encontram protegidas pelo Código do Direito de Autor e Direitos Conexos e demais legislação aplicável, toda a cópia, parcial ou total, deste documento, nos casos em que é legalmente admitida, deverá conter ou fazer-se acompanhar por este aviso.

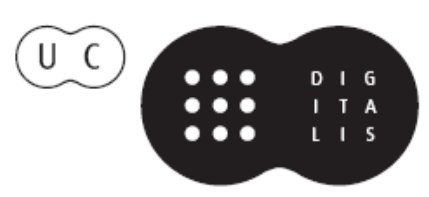




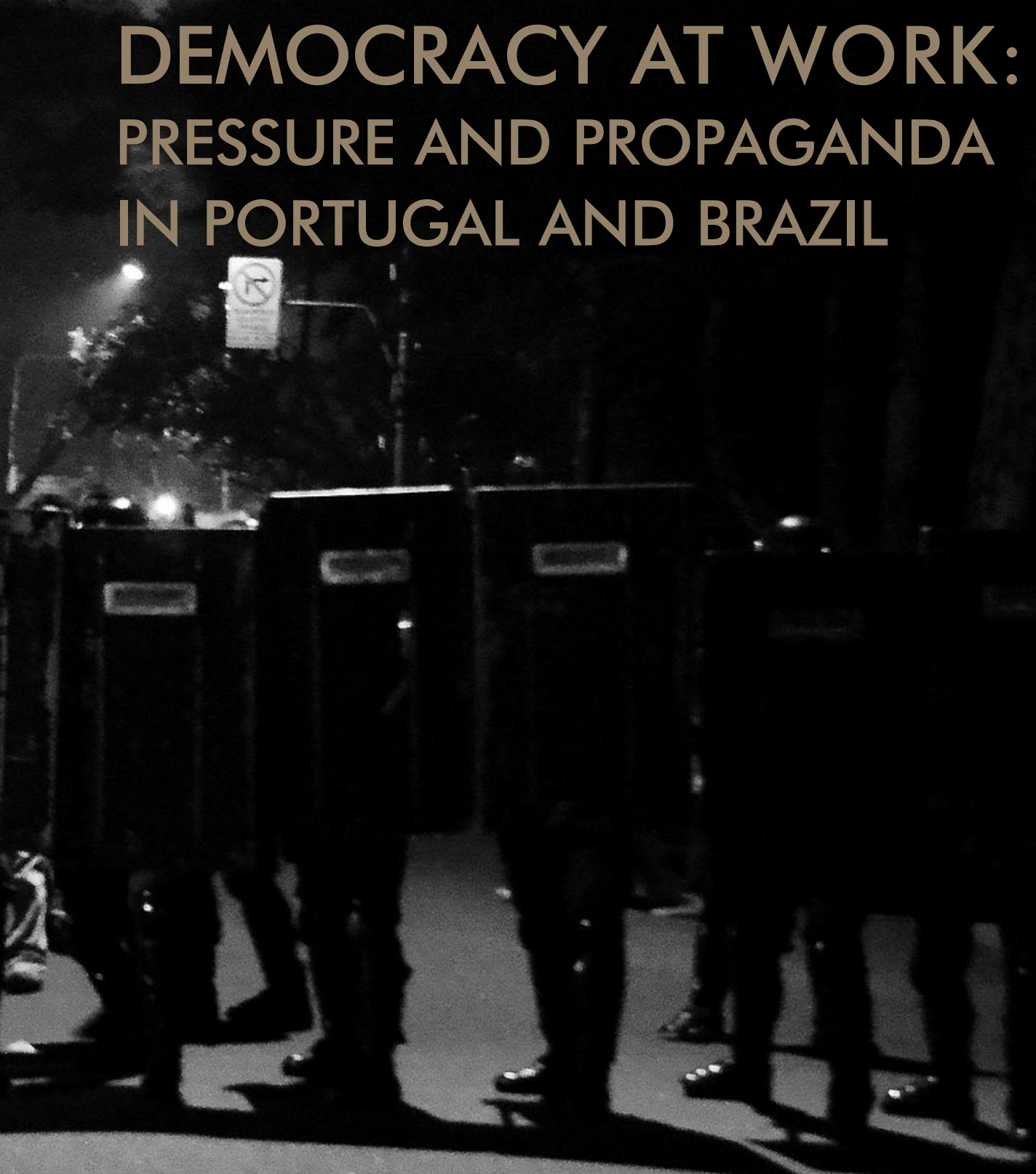

IMPRENSA DA UNIVERSIDADE DE COIMBRA COIMBRA UNIVERSITY PRESS
RITA FIGUEIRAS

PAULA ESPÍRITO SANTO.

ISABEL FERIN CUNHA 


\section{CHA P T E R 4}

\section{BETTER OR MORE INVOLVED IN POLITICS? \\ THE INVOLVEMENT OF PORTUGUESE VOTERS IN \\ PARLIAMENTARY ELECTIONS}

\section{Paula do Espírito Santo}

\section{Introductory note}

The voters' relationship to politics is a classical issue in Political Studies and has undergone important developments on a broad and comparative scale. The citizen's relationship with politics and with the political system have given rise to important concepts such as social capital (Fukuyama 2000, Putnam 1993, 2000), which is a specific reflection of social and political involvement and participation. When analysing the citizen's relationship with politics and with the political system, we should consider political and civic culture concepts. With regard to this topic, we have seen a great deal of contributions beginning with Gabriel Almond's pioneering article, 'Comparative Political Systems', which introduced the concept of political culture in the Journal of Politics, in 1956. However, the idea of political and civic culture has existed and has been expressed for some time, although not necessarily being mentioned by name (Tocqueville, Mead, Benedict) and it is an important conceptual instrument in relation to the individual's relationship with politics and culture. With further reference to this relationship, several contributions have analysed the consequences of political participation from the civil 
community, in terms of the regular citizen's needs of adjusting to how the system is organized and how it is constructed by the State (Fukuyama 1992, Linklater 1998, Lloyd and Thomas 1998, Beck 1998, Klingemann, Fuchs and Zielonka 2006, Inglehart, Haerpfer, Bernhagen and Welzel 2009, Lavareda and Telles 2011).

The focus on how, in democratic systems, people can effectively utilise the system's political answers to their real needs and motives demonstrates a standing process of both adjustment and search, which represents a, permanently, unfolding path to that needs to be followed. However, In 'The Role of Ordinary people in Democratization', Welzel and Inglehart stress that 'the development of effective democracy' reflects the acquisition of resources and values by ordinary people that enable them to pressure the elite, effectively. The importance of this process, known as 'human empowerment' is generally underestimated' Welzel and Inglehart (2008: 126). In other words, the human potential that each Nation contains the basic skills for a better democratic system. 'Democracy can be effective only if power is vested in the people', considering a 'human-empowerment scenario that consists of three elements: action resources, self-expression values and democratic institutions' (Wetzel and Inglehart 2008: 129). These three elements allow a political balance between the powerful elite and the will of the people which can operate at different levels, in relation to each Nation's journey towards an improved Democracy. The most challenging feature of the process of democratization is that it is a major political challenge with what is, probably, a never ending outcome. However, the human capital strength obtained will be greater at each moment in History. As stated by Wetzel and Inglehart (2008: 136) 'the major effect of modernization is not that it makes democracy more acceptable to elites, but that it increases ordinary people's capabilities and willingness to struggle for democratic institutions'.

The importance of political participation is an essential facet of the way the political system, and the citizens in particular, understand and interpret their role as active members of within the State's construction. In a period of time where there is a growing disappointment with the direction that politics and of the economy has taken it appears that there 
is an active repositioning of the relationship between citizens and the political system. In other words, being politically active usually means being less committed to the electoral offer. However, it also means finding and building more demanding links to the political system while searching for more information, the sharing of opinions and a more critical and informed way of living politically. The global and generational growth of education has allowed citizens to reach a political moment in which they are better trained at school and in academic terms and are, therefore, each time more and more critical and knowledgeable about what they want, about politics and about politicians.

\section{Remarks relating to the Political system and methodological aspects}

The Portuguese political system is considered to be of a semi-presidential type. This generally means that there are two basic political ruling institutions of the State and Nation, which are Parliament and the President. In the Portuguese system both Parliament and the President are the principal political institutions of representation. The President is the main political symbol of the Nation, in both internal and international terms, as well as performing the role of supreme political and institutional regulator. The Portuguese political system does have Parliamentary elections every four years and Presidential elections every five years (limited to two consecutive mandates). The President, the Prime-Minister, the President of Parliament, and the Courts are, though, sovereign institutions, in relation to the Portuguese political system.

We considered a three election period, those elections having occurred in 2002, 2005 and 2009 ${ }^{14}$. In 2002 the Prime Minister António Guterres

14 The Portuguese legislative elections, which occurred in 2002 and 2005, were both important and unique. These elections were important due to their inherent nature during a semi-presidential regime. They were also unique for having occurred as a result of singular reasons deriving more from a set of circumstances which had dictated the end of the previous legislature than from the normal and formal reasons that allow for Parliamentary elections to take place every four years. 
resigned due to significant losses in local elections. In the following 2005 elections, the mandatory four year term of office had not been completed because of the dissolution of Parliament. This took place during Pedro Santana Lopes' short term of office as Prime-Minster. Santana Lopes had been appointed after the resignation of the previous incumbent José Manuel Durão Barroso who, after tendering his resignation, was then elected as President of the European Commission.

Methodologically, this study is based upon three post-electoral polls, applied to the urban area around the Portuguese capital, Lisbon. This regional council is known as the 'Greater Lisbon area' and includes the eight councils around Lisbon ${ }^{15}$. The area in question has over 1.5 million voters ${ }^{16}$ from a national electorate of about 9.5 million. This area of this study consists of all of the individuals who are included as voters in the resident electoral register. For each poll the most recently updated data from that year has been used. The electoral register is annually updated by DGAI ${ }^{17}$. The data for the three opinion polls was gathered about one month after the Parliamentary elections had taken place. ${ }^{18}$

The design and implementation of the sampling plan was undertaken in three stages. For the first stage a probabilistic based sampling plan of 600 individual voters was used for each poll. Each council was separated into its political-administrative divisions, according to the number of voters. ${ }^{19}$ At the second 'data collection' stage the random route itinerary technique was applied, which implies contacting the voters at home,

15 The eight councils considered are: Amadora, Cascais, Lisboa, Loures, Odivelas, Oeiras, Sintra and Vila Franca de Xira.

16 In 2002, the electorate consisted of 1,559,986 individuals, according to the current electoral census. In 2005 the electorate consisted of 1,679,706 voters and in 2009: 1590669. Data from STAPE (Secretariado Técnico para os Assuntos do Processo Eleitoral) and DGAI (Direcção geral da Administração Interna).

17 DGAI (Direcção geral da Administração Interna).

18 The elections were held on the $17^{\text {th }}$ March 2002, the $20^{\text {th }}$ February 2005 and the $27^{\text {th }}$ September 2009, respectively.

19 This sampling division was made according to the criteria segmentation of the 'freguesias division (small political administrative divisions similar to borough councils in the UK), related to Law number $169 / 99$, of 18th September and No 8/93, $5^{\text {th }}$ March. 
and following specific itinerary rules. At the third stage the method used was selecting one individual per home, this is in accordance with quota method sampling, where a segmentation of sex and age, based on the last 2001 population census is the recognized procedure. If we consider a poll on a scale of 600 samples, the sampling error would be $\pm 4 \%$, for a $95 \%$ level of confidence, and is considered to be a strictly probabilistic sampling plan.

The data analysis was subject to a principal set of procedures, based upon descriptive statistic analysis. We also used qui-square tests applied on crosstabs applications. Although most of the variables were already tested in other studies, the questionnaire was internally monitored, before being applied, in terms of field work. Several test experiments were also used in order to acquire a better adjustment to Portuguese culture and to reach a suitable level of understanding for the average member of the population. ${ }^{20}$

The hypothesis we constructed is that, when considering Lisbon, which is the principal political Portuguese urban area, in conjunction with the election period from 2002 to 2009, the voters in question tend to be participative, whether in political or electoral terms. Furthermore, our primary question is: 'can we find an evolutionary pattern in political and electoral terms?' As a result, we believe it is both relevant and intriguing since Lisbon is the main political centre for a country of such small dimension as Portugal. According to results obtained from other research that has been undertaken, with comparable data (Cayrol 1989, Inglehart and Andeweg 1993, Boy and Mayer 1997a, Jaffré and Chice 1997, Norris 2001, Welzel and Inglehart 2008, Inglehart, Haerpfer, Bernhagen and Welzel 2009), it may be assumed that within the methodological characteristics of the study, Portuguese voters tend to demonstrate a participative pattern towards politics and elections.

20 The interview' teams were made up of university students, from the Communication Studies' course, of ISCSP (Instituto Superior de Ciências Sociais e Políticas)/UTL (Universidade Técnica de Lisboa), from the 2001/2002 and 2004/2005 and 2009/2010 courses. 


\section{Political involvement and voting perceptions: results}

The political involvement and voting perceptions section refers to a set of variables that seek to describe the political and electoral participation of voters, as well as their perceptions on electoral choice. When referring to 'voters involvement' we mean that which defines the individual's relationship with politics, in political terms, whether it be on an electoral, social or cultural basis. In the present study we take into question a short and consecutive election period, more exactly an evolving three election period (2002, 2005 and 2009). Within this research, the aim is to analyse the importance of various motives, especially the role of the media as a serious constraint and socialization agent on voters' involvement, and also to investigate the role of primary groups and political parties, as examples of relevant aspects that may explain the individuals' relationship to politics. In relation to this matter, we specifically considered five variables which are namely: attitudes and voting behavior; associations of belonging; situations in which the voters participated during the political campaign period; the factors that most influenced the interviewees in their choice of vote; and, finally, the moment when deciding to cast a vote.

In respect of attitudes and voting behavior, relating to the three Parliamentary elections of 20022005 and 2009, the majority of voters stated that they were party supporters and that they had voted in the elections. There was a proportional increase in this group in 2005 , of approximately $11 \%$, according to the post-electoral polls considered (2002: 52\%; 2005: 63\%; 2009: 47\%). This rise and fall of interest in parties indicates a conjuncture phenomenon demonstrating an enthusiasm in 2005 related to José Socrates' own political enthusiasm and personality (table 1). It also appears important to stress the approximately $5 \%$ of individuals who said that they were party members. This amount remained stable over the three election period. This value is slightly above the average value for the individual party members in Portugal. These values can be explained because we are taking into account the largest Portuguese urban area.

From these values we should also underline the number of individuals who said that despite not being party supporters they had still voted in elections. This proportion is similar in the first two polls (around 20\%) - 
2002 and 2005 - and then rose (27\%) - 2009 - which may be interpreted as a tendency to politically walk away from the parties. It means that a move towards politically 'independent' positions is a tendency that is eventually seen. This set of individuals is the most malleable and is more susceptible to influence by electoral campaign actions and, furthermore, is attracted to political-party alternatives. In relation to individuals who are not party supporters and who do not vote in elections, there was evidence of a slight decline between the three post-electoral polls from around 15\% to about $6 \%$ and then an increase back to about $15 \%$. This fall and rise indicates that the group of individuals who, usually, show possible indifference or feelings of rejection to parties and elections may include a significant proportion of politically interested 'converts'. The rise in the percentage of individuals' political and electoral interest which emerged during the 2005 election may be interpreted as high, due to conjuncture reasons. Reasons related to the less popular leadership of Pedro Santana Lopes, who became Prime Minister, after José Manuel Durão Barroso had accepted the post of President of the European Commission, in 2004. Santana Lopes' mandate as Prime Minister lasted less than a year, ending with the dissolution of Parliament by Jorge Sampaio, the President at that time.

Table 1 - Relationship to politics and parties

\begin{tabular}{|c|c|c|c|c|c|c|c|}
\hline & \multicolumn{2}{|c|}{2002} & \multicolumn{2}{|c|}{2005} & \multicolumn{2}{|c|}{2009} \\
\hline & & $\begin{array}{l}\text { Frequen- } \\
\text { cy }\end{array}$ & $\begin{array}{l}\text { Valid per- } \\
\text { centage }\end{array}$ & \begin{tabular}{|l|} 
Fre- \\
quency
\end{tabular} & $\begin{array}{l}\text { Valid per- } \\
\text { centage }\end{array}$ & $\begin{array}{l}\text { Fre- } \\
\text { quency }\end{array}$ & $\begin{array}{l}\text { Valid per- } \\
\text { centage }\end{array}$ \\
\hline \multirow{4}{*}{$\begin{array}{l}\text { Relation } \\
\text { to politics }\end{array}$} & Is a party member & 29 & 4,8 & 29 & 4,8 & 32 & 5,3 \\
\hline & $\begin{array}{l}\text { Is a party supporter } \\
\text { and votes in } \\
\text { elections }\end{array}$ & 312 & 52,0 & 379 & 63,2 & 284 & 47,3 \\
\hline & $\begin{array}{l}\text { Is a party supporter } \\
\text { but does not vote } \\
\text { in elections }\end{array}$ & 45 & 7,5 & 37 & 6,2 & 35 & 5,8 \\
\hline & $\begin{array}{l}\text { Is not a party } \\
\text { supporter but votes } \\
\text { in elections }\end{array}$ & 125 & 20,8 & 116 & 19,3 & 162 & 27,0 \\
\hline \multirow[t]{2}{*}{ Total } & $\begin{array}{l}\text { Is not a party } \\
\text { supporter and } \\
\text { does not vote in } \\
\text { elections }\end{array}$ & 89 & 14,8 & 39 & 6,5 & 87 & 14,5 \\
\hline & & 600 & 100,0 & 600 & 100,0 & 600 & 100,0 \\
\hline
\end{tabular}


The collaboration through membership to associations over the last twelve months is a topic that merits analysing the importance of entering into social participation and its possibilities, as a consequence of an associative phenomenon. The importance of associations in civil society is a traditional object in Political Science and Sociology (Tocqueville, 1835-1840; Roskin et al. 1974, 2003, Almond and Verba 1980, Bacalhau 1991, Putnam 1993, Putnam 2000, Webb, Farrell and Holliday 2002, Whiteley 2008). In Portugal, there is no deep tradition of associationism. The research regarding this subject in Portugal does not afford long-term comparable data. According to one of the first polls used in relation to this issue, the percentage of people who have not joined any associations was about $86 \%$ in 1978, about 84\% in 1984 and about 83\% in 1993 (Bacalhau 1994). This proportion may be deemed high, if we consider the wide range of available civil associations. According to present surveys, which relate to the 'Greater Lisbon area councils, in 2002 the range of individuals who had not become members of an association during the last 12 months was about $67 \%$. This proportion increased to about $75 \%$, in 2005 and fell to $70 \%$ in 2009 . We may consider this to be a significant percentage of people. Those who say that they had not joined any association during the last 12 months were resident in the Lisbon urban area, which is the area offering more facilities and more opportunities for organization and mobilization in association terms.

If we consider those individuals who enrolled in an association over the last 12 months, the highest numbers are attracted to sports, recreation, neighbourhood associations, political parties and church associations. This happened in 2002, 2005 and 2009, despite some slight differences. We should stress that political parties and socio-political associations have a constant and also significant uptake (about 7\%). In relation to this we should consider that political parties in Portugal, and especially in Lisbon, seem to have a mobilizing influence, particularly important in regard to sports or recreational associations. Consequently, we should also take into consideration that parties do play a leading and important role in sensitizing society to political and civic causes. In other words, parties still matter and are actively ahead in civil society association activities. 
Table 2 - Joining into associations during the last twelve months

\begin{tabular}{|c|c|c|c|c|c|c|c|}
\hline & \multicolumn{2}{|c|}{2002} & \multicolumn{2}{|c|}{2005} & \multicolumn{2}{|c|}{2009} \\
\hline & & Frequency & $\begin{array}{l}\text { Valid per- } \\
\text { centage }\end{array}$ & Frequency & $\begin{array}{l}\text { Valid per- } \\
\text { centage }\end{array}$ & Frequency & $\begin{array}{l}\text { Valid per- } \\
\text { centage }\end{array}$ \\
\hline \multirow[t]{10}{*}{ Association } & $\begin{array}{l}\text { Recreative } \\
\text { association }\end{array}$ & 32 & $6,3 \%$ & 24 & 4,0 & 24 & 4,2 \\
\hline & $\begin{array}{l}\text { Sports } \\
\text { association }\end{array}$ & 40 & $7,8 \%$ & 32 & 5,4 & 34 & 5,9 \\
\hline & $\begin{array}{l}\text { Neighborhood } \\
\text { association }\end{array}$ & 18 & $3,5 \%$ & 26 & 4,4 & 39 & 6,8 \\
\hline & Trade unions & 13 & $2,5 \%$ & 5 & ,8 & 19 & 3,3 \\
\hline & $\begin{array}{l}\text { Professional } \\
\text { association }\end{array}$ & 12 & $2,3 \%$ & 14 & 2,3 & 17 & 3,0 \\
\hline & $\begin{array}{l}\text { Church group or } \\
\text { association }\end{array}$ & 19 & $3,7 \%$ & 29 & 4,9 & 30 & 5,2 \\
\hline & $\begin{array}{l}\text { Cultural } \\
\text { association }\end{array}$ & 13 & $2,5 \%$ & 24 & 4,0 & 18 & 3,1 \\
\hline & $\begin{array}{l}\text { Students } \\
\text { association }\end{array}$ & 17 & $3,3 \%$ & 13 & 2,2 & 11 & 1,9 \\
\hline & $\begin{array}{l}\text { Political party or } \\
\text { socio-political } \\
\text { association }\end{array}$ & 34 & $6,7 \%$ & 9 & 6,7 & 37 & 6,5 \\
\hline & $\begin{array}{l}\text { Did not join an } \\
\text { association }\end{array}$ & 341 & $66,7 \%$ & 448 & 75,0 & 402 & 70,2 \\
\hline Total & & 539 & & 663 & & 631 & \\
\hline
\end{tabular}

NOTE: Multiple answer and filter question.

The variable 'situations in which you participated during the political campaign period' is also an important motive for analysis, with regard to the relationship that individuals have with politics. Despite the critical and influential critics of the early 90's about the effects of TV on democracy (Kellner, 1990, Popper and Condry 1993, Lecomte 1993), the social and political impact of TV remains effective. This is also true in spite of the fact that television is quite often not at all linear in the way it really impacts upon democracy (Noelle-Newman 1984, Inglehart Andeweg 1993, Huckfeldt and Sprague 1995, Page 1996, Ramonet 1999). The dramatic as well as the emotional weight of TV are eminent features that, according to Graber's experiments (1996) set up TV as a major source of political information, yet in spite of its massive scale and scope, this medium can reach a wider and extremely heterogeneous audience of citizens, including people with little or no interest in politics. The discussion on the consumption of information about politics stresses the connection between 
political, media consumption and civic engagement. In this regard, from a comparative perspective which includes several countries across Europe and also in the U.S., according to Pippa Norris (2000): 'those most exposed to the news media [...] consistently proved more knowledgeable, not less; more trusting towards government and the political system, not less; and more likely to participate in election campaigns, not less' (Norris 2000: 314). In most western democratic countries, looking at civic engagement is an exercise in discovering a set of constant inputs that reinforce and characterize the nature of the political system. The assimilation of such inputs by the political system and its civic structure, simultaneously, shows a very flexible system which is constantly adapting itself to the multiple circumstances of each political culture. Apart from the multiple inputs that are permanently generated by the system, there are those that are produced by the media, relating to different media types and consequently different patterns of political participation and trust. Comparative data across the E.U.27 reveals TV as being the principal medium of trust (63\%), followed by newspapers ( $43 \%)$, radio $(31 \%)$, the internet $(22 \%)$, written magazines $(8 \%)^{21}$. Some studies have already underlined the importance of the media during a public discussion of the ideas, which tends to have greater impact upon the newspaper readers and, specifically, upon those who have studied further education (Popkin 1991, Norris 2001, Inglehart and Pippa 2009). This tendency, however, shouldn't discourage the need for improving and providing more and better political information, specially, about those with less political competence. The experiments by Tilley and Wlezien (2008) indicate that additional knowledge can be of use to people with low levels of political information and sophistication, motivating a change in their political assessments in an expressive way.

From the various examples of this kind of political participation already mentioned, the most popular within this urban area included the categories of 'watching information on TV about the elections', as well as 'talking about the election with friends and relatives', followed by 'reading posters

${ }^{21}$ Source: European Commission (2009): Special Eurobarometer 308. The Europeans in 2009: http://ec.europa.eu/public_opinion/archives/ebs/ebs_308_en.pdf 
and billboards about the elections.' Each of these three options were found at the top of the 'situations' most experienced, which indicate three different popular sources of participating politically, all of them with significant levels of interest and reflection about politics (and the elections particularly). Comparing to the first two ('watching information on TV about the elections', and 'talking about the election with friends and relatives'), the latter category ('reading posters and billboards about the elections') may be considered to be the most passive and less reactive. This data confirms the tendency that highlights the importance of television as a paramount support mechanism, with regard to political motives. This was also a conclusion that was reached by several surveys in Europe and across the world (Cayrol 1989, Inglehart and Andeweg 1993, Huber and Inglehart 1995, Norris 2001, Inglehart and Norris 2009). It also worth mentioning that about $10 \%$, of individuals in $2002,7 \%$, in 2005 and about 13\%, in 2009 did not experience any of the previously mentioned situations, which is evidence of a lack of interest not only in terms of civic participation but also in relation to the quest for becoming a better informed citizen. A note should be added about the internet and to justify its absence from the data analysed. The use of the internet for campaigning motives, during the nineties, was seen as a secondary resource, with small demand or even investment from politicians, and consequently with limited skills being employed (Lilleaker 2006). During the first decade of the 21st century, however, particularly during the latter years, the internet grew steadily around the world, and in Portugal, too. ${ }^{22}$ However, in political terms, specifically during the 2009 elections $^{23}$ in Portugal, for example, the internet was not as widely exploited and used as it could have been. This is surprising when considering the investments made by the parties, which included inviting group of enterprises and internet specialists, working to promoting that medium (Canavilhas 2012). The limited exploitation of the internet's potential by the campaign sites, in Portugal, also discouraged the electors from using the internet as an attractive source of information, at least that is until this moment.

22 From 2000 to 2009, in Portugal, it grew by $79 \%$ and to about 4 million users (Canavilhas, 2012 and www.internetworldstats.com).

23 There were three elections in Portugal in 2009: Parliamentary, European and Local elections. 
Table 3 - Situations in which you participated during the political campaign period

\begin{tabular}{|c|c|c|c|c|c|c|c|}
\hline & \multicolumn{2}{|c|}{2002} & \multicolumn{2}{|c|}{2005} & \multicolumn{2}{|c|}{2009} \\
\hline & & Frequency & $\begin{array}{l}\text { Valid per- } \\
\text { centage }\end{array}$ & Frequency & $\begin{array}{c}\text { Valid per- } \\
\text { centage }\end{array}$ & Frequency & $\begin{array}{l}\text { Valid per- } \\
\text { centage }\end{array}$ \\
\hline \multirow{9}{*}{ Situations } & $\begin{array}{l}\text { Talked about } \\
\text { the election with } \\
\text { friends and relatives }\end{array}$ & 402 & 67,0 & 417 & 69,5 & 400 & 67,0 \\
\hline & $\begin{array}{l}\text { Talked about the } \\
\text { election with party } \\
\text { members } \\
\text { Attended a public } \\
\text { meeting or a } \\
\text { political party } \\
\text { meeting }\end{array}$ & 113 & 18,8 & 140 & 23,3 & 124 & 20,8 \\
\hline & $\begin{array}{l}\text { Read information } \\
\text { sent by the parties }\end{array}$ & 152 & 25,3 & 211 & 35,2 & 176 & 29,5 \\
\hline & $\begin{array}{l}\text { Read posters and } \\
\text { billboards about the } \\
\text { elections }\end{array}$ & 307 & 51,2 & 338 & 56,3 & 256 & 42,9 \\
\hline & $\begin{array}{l}\text { Read information in } \\
\text { newspapers about } \\
\text { the elections }\end{array}$ & 211 & 35,2 & 223 & 37,2 & 165 & 27,6 \\
\hline & $\begin{array}{l}\text { Watched } \\
\text { information on TV } \\
\text { about the elections }\end{array}$ & 417 & 69,5 & 444 & 74,0 & 380 & 63,7 \\
\hline & $\begin{array}{l}\text { Heard information } \\
\text { on the radio about } \\
\text { the elections }\end{array}$ & 126 & 21,0 & 146 & 24,3 & 128 & 21,4 \\
\hline & $\begin{array}{l}\text { Tried to convince } \\
\text { someone to vote for } \\
\text { a party }\end{array}$ & 44 & 7,3 & 54 & 9,0 & 52 & 8,7 \\
\hline & $\begin{array}{l}\text { Did not experience } \\
\text { any of the above } \\
\text { situations }\end{array}$ & 62 & 10,3 & 42 & 7,0 & 79 & 13,2 \\
\hline Total & & 1857 & & 2039 & & 1798 & \\
\hline
\end{tabular}

NOTE: Multiple answer question.

According to the present analysis, 'watching information on TV about the elections' was an item that was important for groups with differing educational backgrounds. This emphasizes, once again, the importance of television as a means of support with a wide reaching social impact in terms of its influence upon public opinion. In social terms, the importance of education is affected by profession, in this reading. Within 
the category 'talked about the election with friends and relatives', the professions considered as extremely specialized and held in high esteem socio-professionally (for instance: Directors of Public Services and enterprises or liberal professionals), as well as the professions that tend to involve permanent social contact (for instance: administrative staff, sales people, shop assistants, door-keepers) showed a greater tendency to behave in such a manner. These two groups also included those people who tend to have read more information distributed by the parties, as well as those who saw information on posters, billboards, in the press, on television and on the radio. This behaviour, despite being reactive, shows an active and inquisitive attitude and, consequently, seems to indicate the development of an important political involvement in urban Portuguese civil society. This behaviour also reinforces the importance of the media as a key agent in the political socialization process, in an elective act.

Analysing the variables which focus upon factors that had the greatest influence on the interviewees' voting choices, reveals that television was the most frequently chosen category, followed by talking with friends and relatives and, to a lesser extent, newspapers, magazines and radio. These levels of choice are highly similar in both sets of data, in spite of there being a slight decrease of influence in all of these areas as 2009 approached. There is also evidence of a concomitant rise among those who considered that they had not been influenced by any means at all. These categories may not only indicate a conviction in terms of voting choices but also in terms of last minute choices, motivated by indecision. In the three surveys, there were a small proportion of individuals (from 5 to $7 \%$ ) who considered that they had been influenced by polls, in terms of deciding how to cast their vote, which confirms both the importance of opinion poll research mechanisms and also of how public opinion is constructed. Newspapers, magazines and radio were the forms of media that were most selected as well as talking to friends and relatives. 
Table 4 - Main voting choice influences

\begin{tabular}{|c|c|c|c|c|c|c|c|}
\hline & \multicolumn{2}{|c|}{2002} & \multicolumn{2}{|c|}{2005} & \multicolumn{2}{|c|}{2009} \\
\hline & & $\begin{array}{l}\text { Frequen- } \\
\text { cy }\end{array}$ & $\begin{array}{l}\text { Valid per- } \\
\text { centage }\end{array}$ & $\begin{array}{l}\text { Fre- } \\
\text { quency }\end{array}$ & $\begin{array}{l}\text { Valid per- } \\
\text { centage }\end{array}$ & $\begin{array}{l}\text { Frequen- } \\
\text { cy }\end{array}$ & $\begin{array}{l}\text { Valid per- } \\
\text { centage }\end{array}$ \\
\hline \multirow[t]{11}{*}{ Influence } & Radio & 54 & 14,4 & 45 & 10,9 & 47 & 11,0 \\
\hline & $\begin{array}{l}\text { Newspapers and } \\
\text { magazines }\end{array}$ & 91 & 24,2 & 66 & 16,0 & 89 & 20,8 \\
\hline & Television & 230 & 61,2 & 225 & 54,6 & 254 & 59,5 \\
\hline & $\begin{array}{l}\text { Talking to friends } \\
\text { and relatives }\end{array}$ & 115 & 30,6 & 101 & 24,5 & 108 & 25,3 \\
\hline & Party gatherings & 8 & 2,1 & 3 & ,7 & 13 & 3,0 \\
\hline & Meetings & 16 & 4,3 & 11 & 2,7 & 40 & 9,4 \\
\hline & Street propaganda & 29 & 7,7 & 29 & 7,0 & 48 & 11,2 \\
\hline & $\begin{array}{l}\text { Posters and } \\
\text { billboards }\end{array}$ & 16 & 4,3 & 19 & 4,6 & 46 & 10,8 \\
\hline & Polls & 19 & 5,1 & 19 & 4,6 & 30 & 7,0 \\
\hline & None & 75 & 19,9 & 103 & 25,0 & 79 & 18,5 \\
\hline & Do not know & 6 & 1,6 & 3 &, 7 & 7 & 1,6 \\
\hline Total & & 659 & & 714 & & 761 & \\
\hline
\end{tabular}

NOTE: Multiple answer and filter question.

It is important to reinforce the enormous importance of television as an essential mechanism when it comes to forming public opinion in terms of voting choices (table 4). This influence is reflected in news information about political campaigns and also in the debates promoted by television channels with party leaders.

The exchange and promotion of voting and political information between individuals, as part of primary social groups, for example between friends or family is conscientiously expressed, in individual terms, as an important means of persuasion. This reinforces the role of these groups both in relation to the political socialization procedure and also in terms of voting behaviour.

With regard to the moment of deciding which party to vote for (table 5), most individuals stated that they always knew which party they were going to choose (about 66\%; 59\% and 63\% in 2002, 2005 and 2009 respectively). Only a residual amount of voters considered that they had hesitated until the last moment. This percentage of undecided voters increases when the number of people who had already decided how to 
cast their votes before the political campaign is added to the equation. The number of most undecided voters is, however, a little less than a quarter of the total, which is a significant value not only in terms of the necessary space for mobilizing voters but also for political democratic change. This mobilization of voters eventually creates the typical symptom of electoral volatility, for either better or worse, in democratic systems.

Table 5 - Moment of deciding upon which party to vote for

\begin{tabular}{|c|c|c|c|c|c|c|c|}
\hline & \multicolumn{2}{|c|}{2002} & \multicolumn{2}{|c|}{2005} & \multicolumn{2}{|c|}{2009} \\
\hline & & Frequency & $\begin{array}{l}\text { Valid per- } \\
\text { centage }\end{array}$ & Frequency & $\begin{array}{c}\text { Valid } \\
\text { percentage }\end{array}$ & Frequency & $\begin{array}{l}\text { Valid per- } \\
\text { centage }\end{array}$ \\
\hline $\begin{array}{l}\text { Moment } \\
\text { of } \\
\text { Decision } \\
\text { Total }\end{array}$ & $\begin{array}{l}\text { Always } \\
\text { new on } \\
\text { which } \\
\text { party to } \\
\text { vote for }\end{array}$ & 278 & 65,7 & 291 & 59,3 & 290 & 62,9 \\
\hline & $\begin{array}{l}\text { Made his/ } \\
\text { her choice } \\
\text { before the } \\
\text { political } \\
\text { campaign }\end{array}$ & 33 & 7,8 & 68 & 13,8 & 48 & 10,4 \\
\hline & $\begin{array}{l}\text { Made his/ } \\
\text { her choice } \\
\text { during the } \\
\text { political } \\
\text { campaign }\end{array}$ & 52 & 12,3 & 74 & 15,1 & 71 & 15,4 \\
\hline & $\begin{array}{l}\text { Hesitated } \\
\text { until } \\
\text { the last } \\
\text { moment }\end{array}$ & 60 & 14,2 & 58 & 11,8 & 52 & 11,3 \\
\hline & & 423 & 100,0 & 491 & 100,0 & 461 & 100,0 \\
\hline
\end{tabular}

NOTE: Filter question.

From the three polls available we conclude that the people who have always known which party to vote for were older individuals. There were also a greater number of people who identified themselves as having taken that option, which reinforces the importance of consistency of choice for a party among the older generation. On the same note, there were younger voters (18-24 years old) who hesitated until the last moment when it came to casting their vote. We may draw conclusions about the importance of age in relation to the moment of deciding on how to vote, 
as was witnessed at both elections. This importance was confirmed, in statistical terms, by applying the qui-square test $(0,0000)$.

The individuals with further education were those who hesitated the most up until the last moment regarding which party to vote for, as the polls demonstrated. Among those who always knew which party to vote for: the less educated they were the higher the tendency they had to behave in this way. This was a tendency revealed by the polls, in 2002, 2005 and 2009. Also the qui-square test confirmed it $(0,000)$.

We may conclude that the moment of decision regarding voting choices is an important reason for pondering among youngsters as much as it is for more educated individuals. These two analytical lines may enhance the importance of voters' political competence relating to the moment of decision on how to vote. In terms of deciding upon party selection, there is a tendency for greater reflection about the voter's profile, based upon a search for information in the mass media as there also is through interpersonal contact.

\section{Conclusion}

The present analysis relates to the first decade of voter behaviour, within a compared perspective and allowed several aspects and traces concerning the characterization of voter involvement to be articulated. This was undertaken with reference to Greater Lisbon: the major Portuguese area for decisions on voting. The media, particularly television, and primary groups, which are key elements in political socialization, are both extremely important as they directly influence the voting selection process. In connection to this we have found that the relationship of individuals to politics also shows the major influence that the roles of political parties and associations, as agents for political mobilization, have. However, we discovered that most voters always knew which party to vote for (more than $65 \%$ ), and that less than a quarter were more susceptible to the impact of several socialization agents.

Throughout this analysis, we have also concluded that the urban voting population in question is politically participative, specifically concerning 
Parliamentary elections, even though participation in terms of joining associations is somewhat low. It should also be stressed that a larger percentage of individuals are party supporters and they do vote, and that this proportion increased slightly during the three elections time period being analysed. Watching election information on television was one of the most important factors that influenced voting decisions followed closely by talking to friends and relatives. This conclusion allies massive support, such as television, to reactive and reflexive behaviour, such as talking or discussing. This is a very positive and participative way of living and taking decisions about politics and, especially, about democratic systems. This tendency must be contextualised within the slight rise in proportion of those who (although still in a minority) took their decision on which party to vote for during, or at the last moment before, elections. This may be explained as not only being due to circumstantial reasons but also to reasons that may lie in the more comprehensive and reflectional attitudes voters have towards political decision making. Considering the data that has been collated, we are clearly able to confirm our original hypothesis which stated that when considering Greater Lisbon, the principal political Portuguese urban area, and in relation to the first decade of the XXI century, voters tended to be participative, whether in political or electoral terms.

The results achieved, although covering a short time period, demonstrate a sensible attitude from voters who have developed behaviour and a vision that is both electorally and politically participative, something that may be seen as a positive symptom in terms of electoral and political behaviour. This symptom may indicate that voters are politically participative and electorally receptive, whether in terms of paying attention to information about the electoral process or in terms of reflecting upon electoral issues.

\section{References}

Almond, G. and Verba, S. (1980) The Civic Culture Revisited. New York: Little-Brown \& Company.

Bacalhau, M. (1994) Atitudes, Opiniões e Comportamentos Politicos dos Portugueses: 19731993. Lisboa: Edição Mário Bacalhau e Thomas Bruneau. 
Beck, U. (1997) The Reinvention of Politics, Democracy without Enemies. Cambridge: Polity Press.

Boy, D and Mayer, N. (ed.) (1997) L'Électeur a ses Raisons. Paris: Presses de Sciences Po.

Canavilhas, J. (2012) 'E-Campanhas Eleitorais em Portugal: A Internet nas Europeias de 2009' in R. Figueiras (ed.) Os Media e as Eleições: Europeias, Legislativas e Autárquicas de 2009. Lisboa: Universidade Católica Portuguesa.

Cândido, A. (1998) Condições Científicas do Direito de Sufrágio, Lista Múltipla e Voto Uninominal. Coimbra: Coimbra Editora.

Cayrol, R. (1989) 'Le Rôle des Campagnes Électorales' in D. Gaxie (ed.) Explication du Vote, Un Bilan des Études Électorales en France. Paris: Presses de la Fondation Nationale des Sciences Politiques.

Espírito Santo, P. (2006) Sociologia Política Eleitoral - Modelos e Explicações de Voto. Lisboa: ISCSP.

European Commission (2009): Special Eurobarometer 308. The Europeans in 2009: http:// ec.europa.eu/public_opinion/archives/ebs/ebs_308_en.pdf Acessed July 2013.

Fukuyama, F. (1992) The End of History and the Last Man. USA: Penguin Books.

Jaffré, Jérôme, J. C. (1997) 'Mobilité, Volatilité, Perplexité' in D. Boy and N. Mayer (ed.) L'Électeur a ses Raisons. Paris: Presses de Sciences Po.

Huckfeldt, R. and Sprague, J. (1995) Citizens, Politics and Social Communication - Information and Influence in an Election Campaign. New York: Cambridge University Press, 2003.

Inglehart, R.and Andeweg, R.B. (1993) 'Change in Dutch Political Culture: A Silent or a Silenced Revolution?', West European Politics, 16 (3): 345-361.

Inglehart, R. and Norris, P. (2009) Cosmopolitan Communications: Cultural Diversity in a Globalized World. New York: Cambridge University Press.

Inglehart, R., Haerpfer, C., Bernhagen, P. and Welzel, C. (2009) Democratization. Oxford: Oxford University Press.

Kellner, D. (1990) Television and the Crisis of Democracy. Boulder, CO, USA: Westview Press.

Lecomte, P. (1993) Communication Télévision et Démocratie. Paris: Presses Universitaires de Lyon.

Klingemann, .s-D., Fuchs, D. and Zielonka, J. (ed.) (2006) Democracy and Political Culture in Eastern Europe. New York: Routledge.

Lavareda, A. and Telles, H. (2011) Como o Eleitor Escolhe seu Prefeito: Campanha e Voto nas Eleições Municipais. São Paulo: FGV Editora.

Lilleaker, D. (2006) Key Concepts in Political Communication. London: Sage.

Linklater, A. (1998) The Transformation of Political Community - Ethical Foundations of the Post-Westphalian Era. Cambridge: Polity Press.

Lloyd, D. and Thomas, P. (1998) Culture and the State. G.B.: Routledge.

Noelle-Neumann, E. (1984), The Spiral of Silence - Public Opinion - Our Social Skin. Chicago and London: The University of Chicago Press, 1993.

Norri, P. (2001) Digital Divide, Civic Engagement, Information Poverty, and Internet Worldwide. USA: Cambridge University Press.

Norris, P. (2000), A Virtuous Circle. Political Communication in Postindustrial Societies. Cambridge: Cambridge University Press.

Page, B. I. (1996) Who deliberates? Mass Media in Modern Society. Chicago: Chicago University Press. 
Popkin, S. L. (1991) The Reasoning Voter-Communication and Persuasion in Presidential Campaigns. Chicago: The University of Chicago Press.

Popper, K. R. and Condry, J. (1993) La Télévision: Un Danger pour la Démocratie. France: Anatolia Editions.

Putnam, R. D. (1993) Making Democracy Work: Civic Traditions in Modern Italy. USA: Princeton, Princeton University Press.

Putnam, R. D. (2000) Bowling Alone - The Collapse and Revival of American Community. New York: Touchstone Book.

Ramonet, I. (1999) La Tyrannie de la Communication. Paris: Gallimmard, 2001.

Roskin, M., Cord, R., Medeiros, J. and Jones, W. (1974, 2003) 'Political culture' in M.Roskin et al.,Political Science - An Introduction. USA: Prentice-Hall.

Tilley, J. and Christopher, W. (2008) 'Does Political Information Matter? An Experimental Test Relating to Party Positions in Europe', Political Studies, 56: 192-214.

Tocqueville, A. (1835-40/1973), A Democracia na América. Lisboa: Editorial Estúdios Cor.

Webb, P., Farrell, D. and Holliday, I. (eds.) (2002) Political Parties in Advanced Industrial Democracies. Oxford: Oxford University Press.

Welzel, C. and Inglehart, R. (2008) 'The Role of Ordinary people in Democratization', Journal of Democracy, 19: 126-40.

Whiteley, P. (2008) 'Where Have All the Members Gone? The Dynamics of Party Membership in Britain',Parliamentary Affairs. Oxford: Oxford University Press, 53(2): 328-346. 